\title{
低摩擦型すべり支承の面圧・速度依存性検証と 床組免震構造の設計モデル構築
}

\author{
金治英貞 1 ・鈴木直人 $2 \cdot$ 家村浩和 3 ・高橋良和 4 ・美濃智広 5 ・高田佳彦 6 \\ 1正会員 阪神高速道路株式会社 大阪建設部（干559-0034 大阪市住之江区南港北1-14-16） \\ E-mail:kanaji@tech-center.or.jp \\ 2正会員（株）建設技術研究所 大阪支社（广540-0008 大阪市中央区大手前1-2-15） \\ E-mail:n-suzuki@ctie.co.jp \\ 3フェロー 京都大学教授 工学研究科都市社会工学専攻（广606-8501 京都市左京区吉田本町） \\ E-mail: iemura@catfish.kuciv.kyoto-u.ac.jp \\ 4 正会員 京都大学助手 工学研究科都市社会工学専攻 ( \\ E-mail: yos@catfish.kuciv.kyoto-u.ac.jp \\ 5 正会員（株）建設技術研究所 大阪支社（广540-0008 大阪市中央区大手前 1-2-15） \\ E-mail:mino@ctie.co.jp \\ 6 正会員 阪神高速道路株式会社 技術管理室（干541-0056 大阪市中央区久太郎町 4-1-3) \\ E-mail: yoshihiko-takada@hanshin-exp.co.jp
}

\begin{abstract}
本論文は, 長大トラス橋の地震時性能向上を目的とした床組免震構造を対象として, 低摩擦型すべり支 承と積層ゴムで構成された免震構造の動的特性を実験的，解析的に明らかにしたものである。ここでは， 速度依存性，面圧依存性を有する低摩擦型すべり支承と積層ゴム，および上部桁から構成される試験体を 用いた振動台実験を実施し, 特に, 実橋における主構の動特性により増幅された鉛直振動の影響に着目し ている. 次に, 低摩擦型すべり支承の特性をモデル化した1質点系モデルによる解析結果と実験結果を比 較し，面圧変動を死荷重面圧との関係で無次元化し応答影響を明らかとするとともに，速度依存性が高い 低摩擦型すべり支承を用いる場合の実務設計用モデルの構築を等価摩擦係数を用いて行っている.
\end{abstract}

Key Words: long-span bridge, seismic retrofit, low friction sliding bearing, shaking table test, velocity dependency, pressure dependency, hybrid floor isolation system

\section{1. はじめに}

最近の研究により，長大トラス橋のレベル 2 地震 動に対する地震時性能向上策として，道路面である 床組構造を免震化させる方法（以下，「床組免震構 造」）が有効な手法であることが明らかにされてい る ${ }^{1)}$. その装置としてはゴム支承系とす心゙り支承系 に大きく分類できるが, ここでは, 既設橋梁への適 用の観点から既存支承の設置空間を考慮し, 支承高 の低いす心゙り支承を鉛直支持装置とする「すべり免 震支承システム」に着目している。つまりここで対 象としたのは，「す心゙り免震支承システム」を用い た「床組免震構造」である. システムと呼んでいる のは，免震機能を期待する装置としてのすべり免震 支承（以下，「寸べり支承」）の他に, 復元力と周 期調整，さらに場合によっては減衰付与の役割を果 た寸装置として水平荷重分散装置（本研究では以下,
「積層ゴム」）が用いられることによる．このすべ り免震支承システムは, 兵庫県南部地震以降, 採用 されはじめた構造であり ${ }^{2)}$ ，今では機能分離支承の ひとつの形態としても整理可能である ${ }^{3), 4)}$.

わが国における一般橋に対するすべり支承に関す る研究は, 兵庫県南部地震以前から岡本らによって 実施されており, 従来の PTFEすべり材とステンレ 又鋼板の摩擦による免震機能に関して, 実験的ある いは解析的成果が明らかとされている ${ }^{5), 6)}$ 。ここで は, これらの材料の摩擦係数は, 面圧や速度依存性 のために変動すること, 一般橋を対象とした動的効 果に関しては, 支承変位を低減させる観点で摩擦係 数は大きい方が望ましいことが示されている.また 水平・鉛直同時入力に関する実験も行なわれており， 鉛直最大加速度約 $0.4 \mathrm{G}$ の範囲において鉛直動の影 響は見られないとの結果が示されている.さらに, 速度依存性の影響は考慮する必要がないとの結論を 


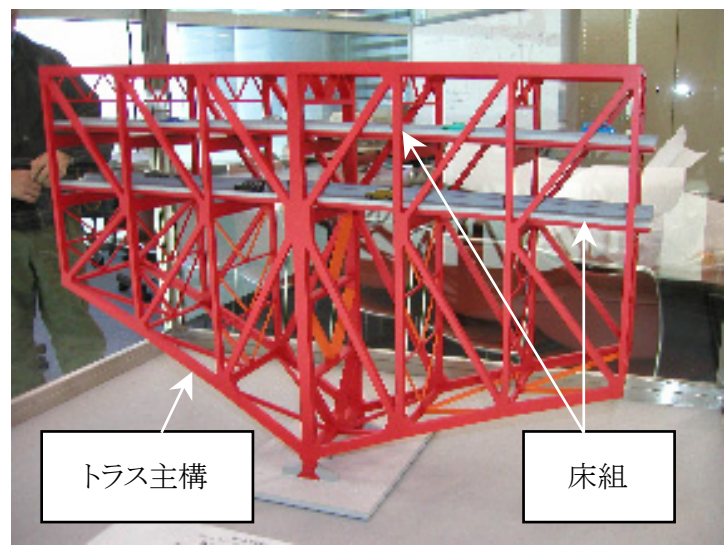

図-1 トラス主構と免震対象の床組

導いている．また，同様の材料に対するすべり支承 のモデル化に関して言えば，川島による研究 7)をは じめとして，最近では，面圧依存性等を考慮した， 高橋ら ${ }^{8)}$ や姫野・運上 ${ }^{9}$ による研究がある。ささらに,

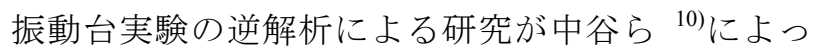
て行われている.

米国では AASHTO Guide Specifications for Seismic Isolation Design ${ }^{11)}$ においてすべり免震支承の基準化 が進んでおり，1991 年版の発行時点からすべり免 震支承の適用事例が増加している背景のもと, 1999 年版 ${ }^{12)}$ ではこの詳細内容が追加されている現状に ある. この示方書には, 材料から品質試験に至るま ですべり免震支承の規定がなされているが，面圧依 存性や速度依存性に関する記載は見当たらない。な お，FPS とよばれる摩擦面が球面の支承が開発され 規定されていることも特筆できる.

今回対象としている床組免震構造は, 図-1に示寸 ような長大トラス橋の主構造中の床組のみを免震化 させるものであり，これまでの橋脚に支持された上 部構造を免震化させる構造とは異なっている。この ため, 解析結果から, トラス主構の断面力低減効果 を期待する場合, 既存のすべり支承より低摩擦（摩 擦係数 0.05 程度) の寸べり支承が要求され ${ }^{1)}$, 新材 料によるす心゙り支承が開発された ${ }^{13), 14)}$.

以上の背景から, 既往の研究, 設計において対象 とされていたPTFEすべり材とステンレス鋼板に関 する知見とは異なる, 新材料による低摩擦型すべり 支承の摩擦特性を把握するとともに, その速度依存 性や面圧依存性が，すべり支承と積層ゴムを有する システムとしての動的挙動にどのような影響を与え るのかを評価する必要が生じた，特に今回考案され た床組免震構造の鉛直振動は, 主構の動特性の影響 を受け, 基礎位置における水平地震動により励起さ れるとともに，鉛直地震動により増幅される特性を 有している. 本研究ではその影響に着目しているこ

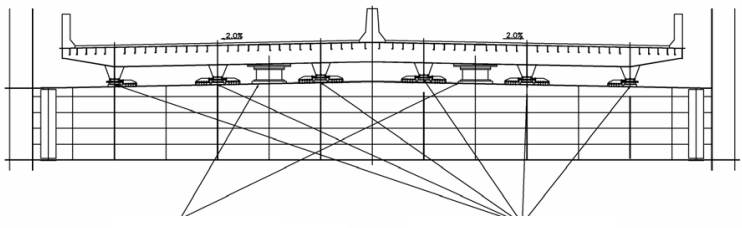

積層ゴム

すべり免震支承

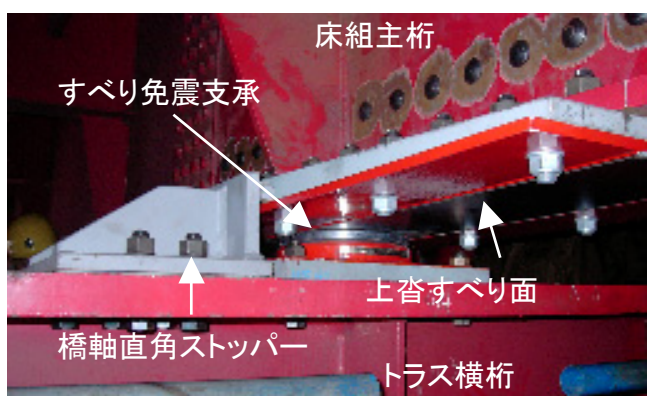

図-2 床組免震機構（上）とす心゙り免震支承（下）

とが特徵である.

具体的には，増幅された鉛直振動を考慮した振動 台実験を実施した後, 要素実験に基づくすべり支承 の数值モデルを用いて再現解析を実施している。ま た, 再現性が確認された詳細モデルを用いて, 解析 的に死荷重面圧との比率で無次元化された面圧変動 の特性検討を実施した上で，実務設計を意識した簡 易な設計モデルの提案を行っている. なお，ここで 開発された同種の低摩擦型すべり支承を用いた，面 圧変化の小さい連続桁橋の免震効果に関する研究が 大塚ら ${ }^{15)}$ によって実施されているが，ここでのす心゙ り支承のバイリニアモデルの設定は高速載荷実験で 得られた高速度時の摩擦係数に基づき行われている. これに対して, 本研究では汎用性をもたせるために, 設計速度との関係に基づく等価摩擦係数を用いた剛 塑性型バイリニアモデル構築を目的としている.

\section{2. 床組免震構造の振動台実験による動的特性}

\section{(1) 床組免震構造と振動台実験概要}

対象橋梁の原状床組（鋼床版桁）は，荷重を支承 板で支持するタイプの鋼製支承（支承板支承）によ り，トラス横桁上に固定あるいは可動支持された構 造である. しかし，レベル 2 地震動に対するトラス 主構の応答低減が必要となったことから，これらの 支承をすべり支承に取り替える対策が採用されてい る ${ }^{1)}$. 採用されている免震構造を図-2に示寸，なお， す心゙り支承として，平板タイプを採用している.

このシステムの特性は, す心゙り材の摩擦係数と水 平荷重分散装置である積層ゴムの剛性に依存するこ とはよく知られており, 一般橋については種々の解 


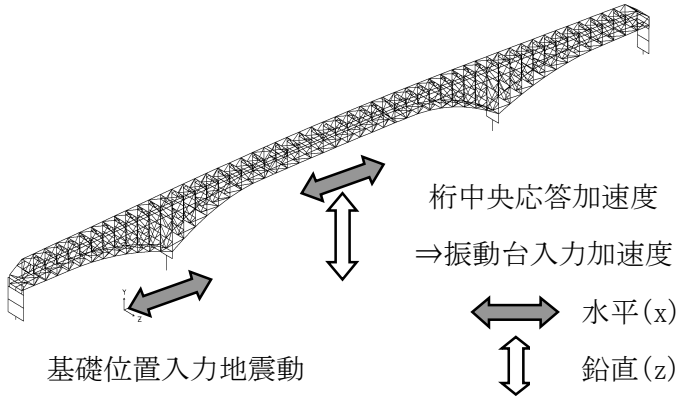

a) 水平地震動の場合

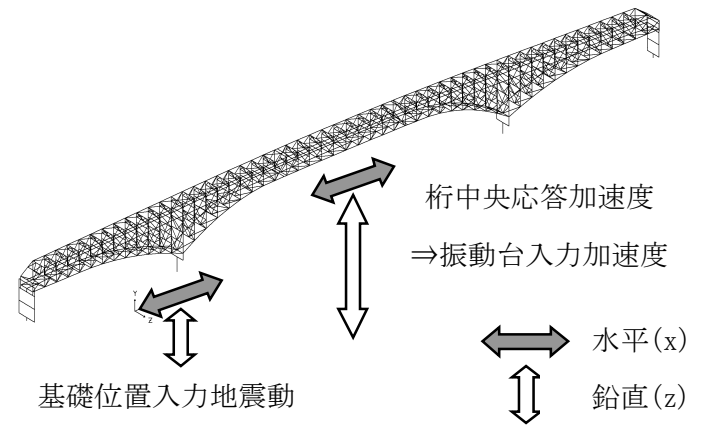

b) 水平十鉛直地震動の場合

図-3 基礎位置入力地震動と振動台入力加速度の関係

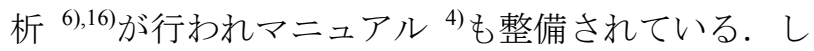
かしながら，本橋は一般橋のす心゙り免震と異なり， 重量の大きな主構の中の一部である床組が免震化さ れるために, PTFE すべり材とステンレス鋼板の摩 擦係数とは異なる低摩擦型のすべり支承が必要とな った。これまでこのような支承は，わが国の橋梁に 採用されたことはなく新たに開発するに至った。こ のため, その動特性である速度依存性, 面圧依存性 に着目し，設計照査用入力地震動を用いて求められ た床組位置での鉛直振動を考慮した振動台実験によ り，すべり支承と積層ゴムを併設したすべり免震支 承システムとしての性能を検討することとした。

具体的な検討事項は, 入力地震動の違いによる応 答值の比較, 免震効果, 鉛直振動の影響, 速度 - 面 圧依存性である。

試験体の詳細は後述するが，対象橋梁中の複数あ る床組のひとつである 4 径間連続鋼床版 I 桁を抽出 し, トラス主構の横桁より上の部分のみの動的挙動 に着目している.つまり，振動台実験における振動 台はトラス主構の横桁に相当し，これに支持された すべり支承および積層ゴムと床組を模擬する試験桁 により実験を行う。ここで，振動台に入力すべき加 速度は，基礎位置における入力地震波形とは異なり， これを用いて 3 次元全橋モデルにより解析して得ら れたトラス中央部の横桁位置での応答加速度である

（図-3参照）。なお，支承モデルは概略設計時の諸 元を用いた等価線形モデルを用いている. 中央部の
表-1 振動台試験機諸元

\begin{tabular}{l|l}
\hline 最大載荷荷重 & $150 \mathrm{kN}(15 \mathrm{tf})$ \\
\hline 振動台 & 3 軸 6 自由度の振動台 $5.0 \mathrm{~m} \times 3.0 \mathrm{~m}$ \\
\hline \multirow{2}{*}{ 最大変位 } & $\begin{array}{l}\mathrm{X} \text { 方 向 } \pm 300 \mathrm{~mm}, \mathrm{Y} \text { 方 向 } \\
\pm 250 \mathrm{~mm}, \mathrm{Z} \text { 方向 } \pm 200 \mathrm{~mm}\end{array}$ \\
\hline 最大速度 & $\mathrm{X}, \mathrm{Y}, \mathrm{Z}$ 方向 $150 \mathrm{kine}$ \\
\hline 最大加速度 & $\mathrm{X}, \mathrm{Y}, \mathrm{Z}$ 方向 $\pm 1.0 \mathrm{G}$ \\
\hline 周波数 & $0.1 \sim 50 \mathrm{~Hz}$ (上載荷重 $15 \mathrm{tf}$ の場合 $)$ \\
\hline
\end{tabular}

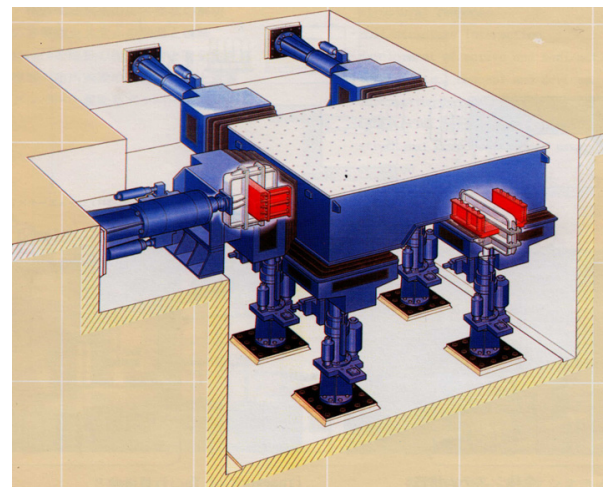

図-4 振動台試験機構造

表-2 実橋と試験体の相似則

\begin{tabular}{c|c|c|c}
\hline 対象 & 試験体/実橋 & 対象 & 試験体/実橋 \\
\hline 長さ, 変位 & $1 / \lambda$ & 加速度 & 1 \\
\hline 面圧 & 1 & 速度 & $1 / \sqrt{\lambda}$ \\
\hline 時間 & $1 / \sqrt{\lambda}$ & 周期 & $1 / \sqrt{\lambda}$ \\
\hline 質量 & $1 / \lambda^{2}$ & 慣性力 & $1 / \lambda^{2}$ \\
\hline 剛性 & $1 / \lambda$ & \multicolumn{1}{|l}{}
\end{tabular}

床組を対象とした理由は，鉛直振動の振幅が相対的 に大きいことによる.

\section{(2) 試験機と試験体}

\section{a) 試験機}

本実験では3次元入力地震動を再現可能とする京 都大学防災研究所に設置されている振動台試験機を 用いた。 その諸元は表-1，構造は図-4の通りである.

\section{b) 試験体}

本実験は面圧・速度変化によるすべり免震支承シ ステムの影響について検討するものである．実験で は支承部のすべり現象を十分な精度で再現させるこ とが重要であることから，桁の慣性力とすべり支承 の摩擦力の比を実橋と実験モデルで一致させるため に，加速度の相似比を 1.0 とする。加速度の条件に 加えて, すべり支承の面圧比を 1.0 として, 長さの 比 $1 / \lambda$ の条件を考慮すると, 相似則 ${ }^{17)}$ は表-2のよう になり，これに従い算出した試験体諸元は表-3の通 りである。

試験体設置状況と支承配置状況を図-5に示すが， 
表-3 実橋と試験体の諸元（相似率 $\lambda=8.75 ）$

\begin{tabular}{l|l|l}
\hline & \multicolumn{1}{|c}{ 実橋 } & \multicolumn{1}{c}{ 試験体 } \\
\hline 上部構造重量 & $7,500 \mathrm{kN}$ & $98 \mathrm{kN}$ \\
\hline 上部構造固有周期 & 3.00 秒 & 1.01 秒 \\
\hline 積層ゴム剛性 & $1.068 \mathrm{kN} / \mathrm{mm}$ & $0.122 \mathrm{kN} / \mathrm{mm}$ \\
\hline すべり支承面圧 & $19.5 \mathrm{~N} / \mathrm{mm}^{2}$ & $19.5 \mathrm{~N} / \mathrm{mm}^{2}$ \\
\hline 平均摩擦係数 & 約 0.05 & 約 0.05 \\
\hline
\end{tabular}
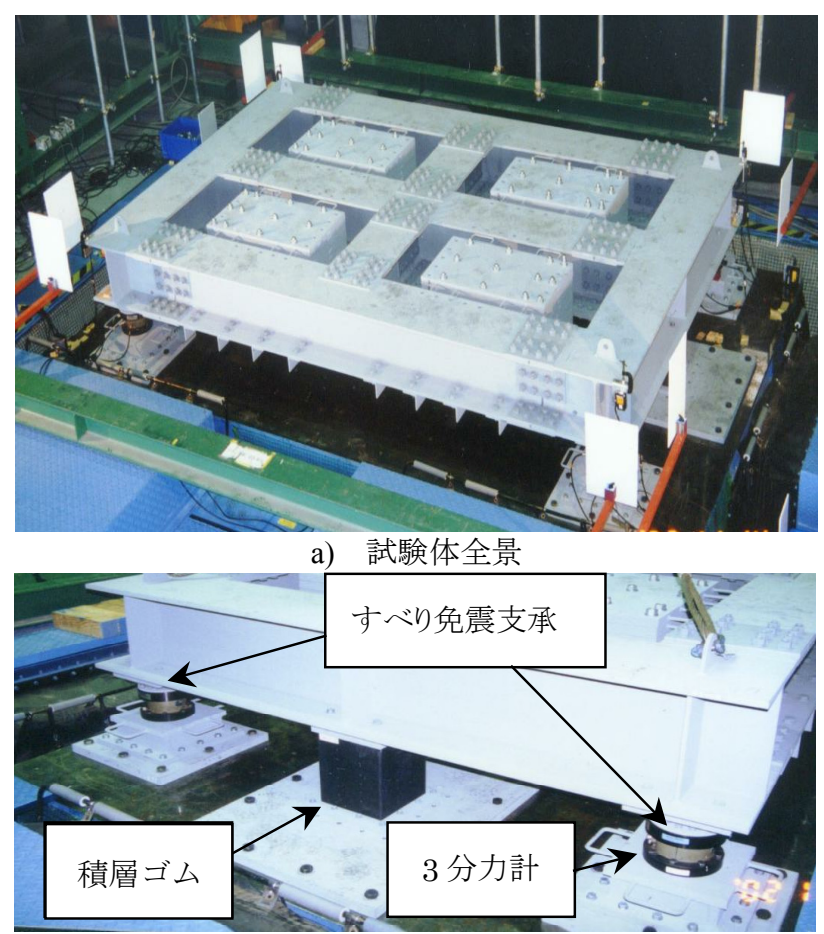

b）免震支承システム詳細

図-5 試験体設置状況

すべり支承は試験林の四隅に各1個の合計4個，また， 積層ゴムは試験桁の短辺中央に各 1 個, 合計 2 個設置 している．なお，本実験では面圧・速度変化による 摩擦係数の変化について計測する必要があることか ら，各々のすべり支承下面に3分力計を設置した.

\section{c)すべり免震支承と積層ゴム}

すべり支承試験体を図-6に示す，すべり支承試験 体は，実験における所定の変位量を考慮して構造寸 法を決定し，すべり材径は面圧の相似則を満足する ために $40 \mathrm{~mm}$ とした。材料の組み合わせは低摩擦係 数を実現するため, 基本性能試験結果から, すべり 材に繊維強化熱硬化樹脂, 上沓すべり板にフッ素樹 脂コートを施したステンレス鋼板を用いた。積層ゴ ム試験体を図-7に示す。ゴム試験体は，実験におい て必要とされる復元性能, つまり積層ゴム剛性より 構造寸法を決定した.

\section{(3) 実験方法}

対象橋梁においては，当該地域における複数の想
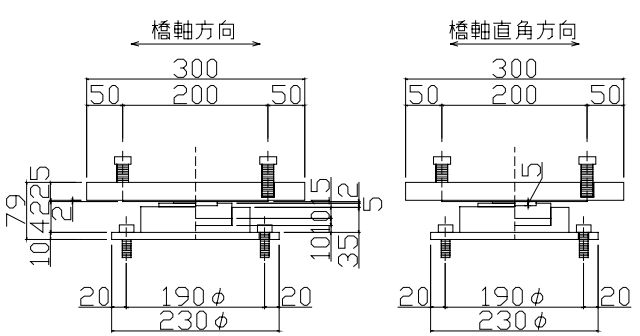

単位 : mm

図-6 すべり免震支承とす心゙り材（右下）

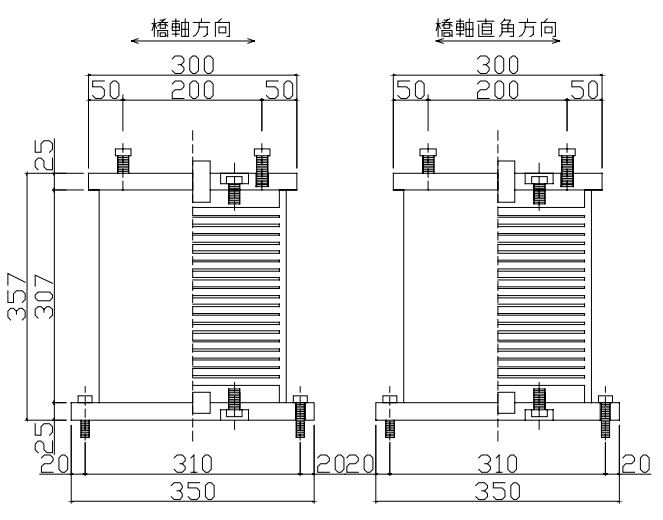

単位: $\mathrm{mm}$

図-7 積層ゴム

表-4 実験ケース

\begin{tabular}{|c|c|c|}
\hline $\begin{array}{c}\text { 実験ケー } \\
\text { ス }\end{array}$ & $\begin{array}{l}\text { 対象入力地震動 } \\
\text { (基礎位置加速度) }\end{array}$ & $\begin{array}{l}\text { 桁位置最大加速度 } \\
\text { (振動台最大加速度) }\end{array}$ \\
\hline $\mathrm{T} 1$ & $\begin{array}{l}\text { 内陸型 I 波 } \\
\text { (水平のみ) }\end{array}$ & $\begin{array}{l}\text { 水平 } 6.54 \mathrm{~m} / \mathrm{s}^{2} \\
\text { 鈆直 } 3.10 \mathrm{~m} / \mathrm{s}^{2}\end{array}$ \\
\hline $\mathrm{T} 2$ & $\begin{array}{l}\text { 内陸型 I 波 } \\
\text { (水平+鈆直) }\end{array}$ & $\begin{array}{l}\text { 水平 } 6.83 \mathrm{~m} / \mathrm{s}^{2} \\
\text { 鉛直 } 5.75 \mathrm{~m} / \mathrm{s}^{2}\end{array}$ \\
\hline T3 & $\begin{array}{l}\text { 内陸型 II 波 } \\
\text { (水平のみ) }\end{array}$ & $\begin{array}{l}\text { 水平 } 3.28 \mathrm{~m} / \mathrm{s}^{2} \\
\text { 鉛直 } 1.50 \mathrm{~m} / \mathrm{s}^{2}\end{array}$ \\
\hline $\mathrm{T} 4$ & $\begin{array}{l}\text { 内陸型 IV 波 } \\
\text { (水平のみ) }\end{array}$ & $\begin{array}{l}\text { 水平 } 4.49 \mathrm{~m} / \mathrm{s}^{2} \\
\text { 鉛直 } 2.00 \mathrm{~m} / \mathrm{s}^{2}\end{array}$ \\
\hline T5 & $\begin{array}{c}\text { 海溝型 } \\
\text { (水平のみ) }\end{array}$ & $\begin{array}{l}\text { 水平 } 1.70 \mathrm{~m} / \mathrm{s}^{2} \\
\text { 鉛直 } 1.02 \mathrm{~m} / \mathrm{s}^{2}\end{array}$ \\
\hline
\end{tabular}

定地震動を用いた設計が実施されている1). そこで, これらの地震波である内陸型波，II波，IV波および 海溝型地震波を3次元全橋モデルに入力して解析し， 対象とした床組位置での応答加速度を算出した。 そ して，得られた応答加速度を振動台に入力した。 な お，実橋における床組免震構造は，橋軸方向の夕可 動で，橋軸直角方向には低摩擦材を貼付したストッ パーで変位拘束する構造であることから, 水平方向 に関しては1方向載荷としている。

実験ケースを表-4に示す。ここで，対象橋梁基礎 位置での入力地震動としては，ケース $\mathrm{T} 2$ を除き, 水平成分のみの入力であるが，振動台入力において 


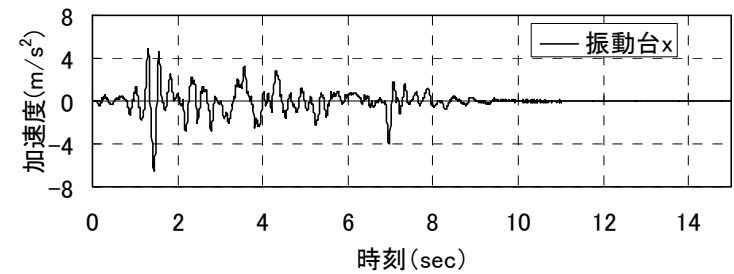

a) 水平加速度

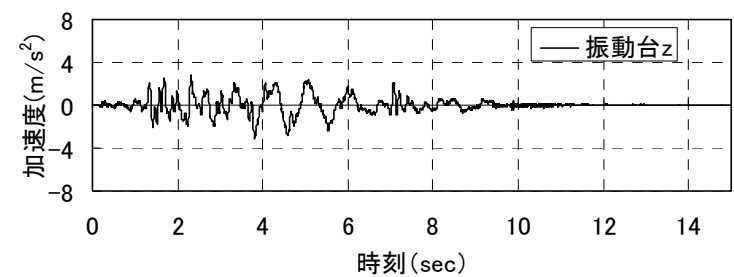

b) 鉛直加速度

図-8＼cjkstart実験ケース $\mathrm{T} 1$ の振動台加速度

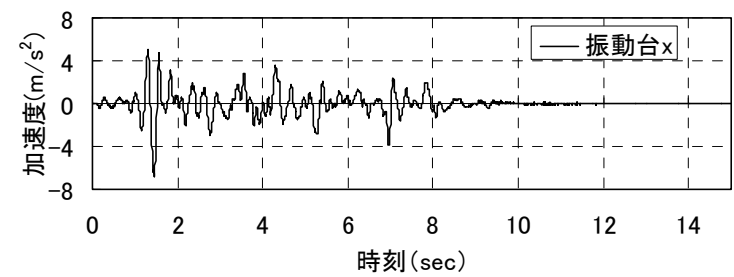

a) 水平加速度

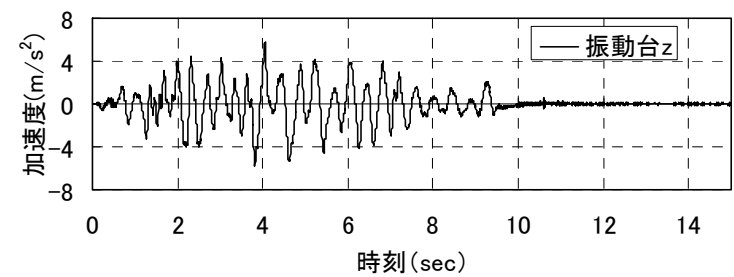

b) 鉛直加速度

図-9 実験ケース T2 の振動台加速度

は，橋梁全体系における動的特性により水平十鉛直 成分入力となる. ケース $\mathrm{T} 1$ と $\mathrm{T} 2$ の振動台加速度 を図-8, 図-9に示す。ケース T2 は図-3b)に示すよ うに入力地震動も鉛直成分を入力しており，振動台 入力は当然ながら水平＋鉛直成分であり，鉛直成分 はケース T1に比べて大きな值となっている.

\section{(4) 実験結果}

\section{a) 主要値の比較}

各実験ケースにおける桁およびすべり支承の最大 応答值を表-5に示す.

桁相対変位は, 内陸型 $\mathrm{I}$ 波を入力したケース $\mathrm{T} 1$ において $81.7 \mathrm{~mm}$ と最大值を示しており，ケース T3（内陸型 II 波），およびケース T4（内陸型 IV 波）においては，比較的小さな值となっている，桁 相対速度および桁相対加速度も桁相対変位と同様に
表-5 実験における桁およびすべり支承の最大応答值

\begin{tabular}{c|c|c|c|c}
\hline $\begin{array}{c}\text { 実験欠 } \\
\text { 一 }\end{array}$ & $\begin{array}{c}\text { 桁相対 } \\
\text { 変位 } \\
(\mathrm{mm})\end{array}$ & $\begin{array}{c}\text { 椼相対 } \\
\text { 速度 } \\
(\mathrm{m} / \mathrm{s})\end{array}$ & $\begin{array}{c}\text { 桁相対 } \\
\text { 加速度 } \\
\left(\mathrm{m} / \mathrm{s}^{2}\right)\end{array}$ & $\begin{array}{c}\text { 摩擦力 } \\
(\mathrm{kN})\end{array}$ \\
\hline \hline $\mathrm{T} 1$ & 81.7 & 0.668 & 3.65 & 12.0 \\
\hline $\mathrm{T} 2$ & 58.5 & 0.533 & 2.75 & 11.3 \\
\hline $\mathrm{T} 3$ & 15.7 & 0.169 & 1.58 & 11.1 \\
\hline $\mathrm{T} 4$ & 10.3 & 0.221 & 1.36 & 12.0 \\
\hline $\mathrm{T} 5$ & 4.30 & 0.068 & 1.15 & 11.0 \\
\hline
\end{tabular}

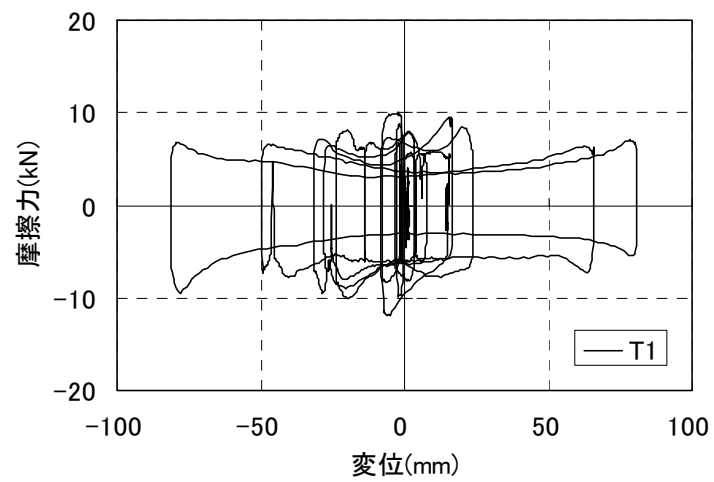

a) ケース $\mathrm{T} 1$

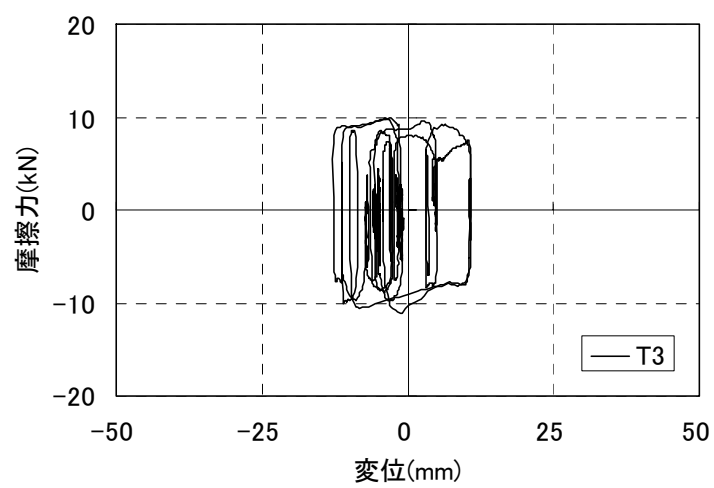

b) ケース T3

図-10 すべり支承（4個分）の履歴曲線の比較

ケース $\mathrm{T} 1$ が最大值を示している. 3 分力計で測定 したすべり支承の摩擦力は多少ばらつきがみられる ものの，ほぼ $11 \mathrm{kN} \sim 12 \mathrm{kN}$ と一定值を示しており， いずれのケースにおいてもすべりが発生しているこ とを示すものである.

すべり支承 4 個の合計の履歴曲線を図-10に，支 承部の履歴面積および等価減衰定数を表-6および 表-7に示す。ここで，積層ゴムの反力は直接計測が できないことから，桁慣性力と桁相対変位から求め た全体系の履歴曲線と 3 分力計によるすべり支承の 履歴曲線を用い，この差分を解析することにより推 定した。

この結果より，桁忘答と同様に，全体系，すべり 支承，および積層ゴム履歴面積いずれもケース $\mathrm{T} 1$ 
表-6 実験における支承部履歴面積

\begin{tabular}{|c|c|c|c|}
\hline \multirow{2}{*}{$\begin{array}{c}\text { 実験厅一 } \\
\text { ス }\end{array}$} & \multicolumn{3}{|c|}{ 履歴面積 $(\mathrm{kN} ・ \mathrm{~mm})$} \\
\hline & 全体系 & すべり支承 & 積層ゴム \\
\hline $\mathrm{T} 1$ & $\begin{array}{c}2,089 \\
(100 \%) \\
\end{array}$ & $\begin{array}{r}1,370 \\
(66 \%) \\
\end{array}$ & $\begin{array}{c}719 \\
(34 \%) \\
\end{array}$ \\
\hline $\mathrm{T} 2$ & $\begin{array}{c}1,549 \\
(100 \%) \\
\end{array}$ & $\begin{array}{c}1,174 \\
(76 \%) \\
\end{array}$ & $\begin{array}{c}375 \\
(24 \%) \\
\end{array}$ \\
\hline T3 & $\begin{array}{c}330 \\
(100 \%) \\
\end{array}$ & $\begin{array}{c}324 \\
(98 \%)\end{array}$ & $\begin{array}{c}6 \\
(2 \%) \\
\end{array}$ \\
\hline $\mathrm{T} 4$ & $\begin{array}{c}353 \\
(100 \%)\end{array}$ & $\begin{array}{c}343 \\
(97 \%)\end{array}$ & $\begin{array}{c}10 \\
(3 \%)\end{array}$ \\
\hline T5 & $\begin{array}{c}155 \\
(100 \%)\end{array}$ & $\begin{array}{c}156 \\
(100 \%)\end{array}$ & $\begin{array}{c}0 \\
(0 \%)\end{array}$ \\
\hline
\end{tabular}

（）值は比率を示す

表-7 実験における支承部等価減衰定数

\begin{tabular}{c|c|c}
\hline \multirow{2}{*}{ 実験ケース } & \multicolumn{2}{|c}{ 等価減衰定数 } \\
\cline { 2 - 3 } & すべり支承 & 積層ゴム \\
\hline \hline $\mathrm{T} 1$ & $25 \%$ & $4.7 \%$ \\
\hline $\mathrm{T} 2$ & $32 \%$ & $4.9 \%$ \\
\hline $\mathrm{T} 3$ & $42 \%$ & $1.3 \%$ \\
\hline $\mathrm{T} 4$ & $48 \%$ & $2.7 \%$ \\
\hline $\mathrm{T} 5$ & $60 \%$ & $0 \% *$ \\
\hline
\end{tabular}

*本值は計測誤差により僅かにマイナス值を示したが $0 \%$ と表示とした.

が最大となった。ところで積層ゴムには設計上減衰 を考慮しないのが一般的であるが，履歴面積はケー ス T1 において $34 \%$ と大きな比率を占めており，全 体系履歴面積が小さくなるほどその比率は小さなも のとなっている。これは, 変位の増加に伴い減衰が 増加する積層ゴムの特性による，ケース T3（内陸 型 II 波），ケース T4（内陸型 IV 波），ケース T5

（海溝型）においては無視しえる值である。また， 等価減衰定数に関しては, ケース $\mathrm{T} 1$ および $\mathrm{T} 2$ に おいて，すべり支承の值が小さな值となっている. この原因は，す心゙り支承の速度依存性によるもので ある。つまり，ケース $\mathrm{T} 1$ や $\mathrm{T} 2$ においては桁相対 速度が大きくなっており, 図-10a)に示すようにす べり支承の履歴曲線が，他のケースに見られる剛塑 性形と異なり鼓形になっていることに起因している.

\section{b) 免震効果}

ケース $\mathrm{T} 1$ を例にとり, 加速度を指標とした免震 効果を考察する. 図-11は, 横軸を振動台加速度, 縦軸を桁応答加速度とした 0.005 秒ごとの各関係で ある。 なお，履歴曲線の折り返し点（すべり支承の 摩擦力の符号が反転する範囲）付近のデータは, 計 測上の問題を含むため除去している。この図におい て斜めの破線は両指標が同一值を示す線であること から，これより下方にあれば免震効果が発揮されて

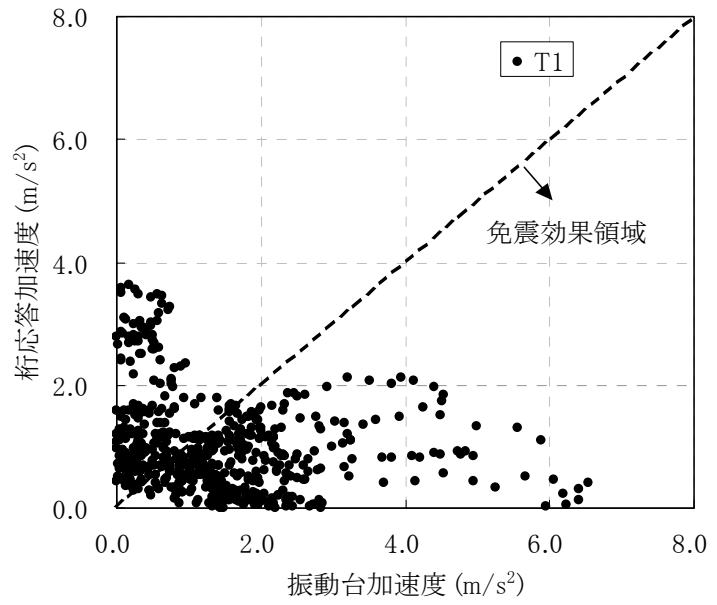

図-11 免震効果（ケース $\mathrm{T} 1$ )

いることになる。

振動台加速度が $2 \mathrm{~m} / \mathrm{s}^{2}$ 以上の領域においては免震 効果が出始め, 特に振動台の最大加速度近くなると, 桁応答加速度は十分に小さくなり免震効果は大きく なることがわかる。しかしながら， $2 \mathrm{~m} / \mathrm{s}^{2}$ 以下にお いては桁応答が増幅されているプロットがある．特 に，増幅率が高い時刻は 4 秒前後であることがわか っている．この時間帯に着目すると，桁変位の周期 は約 1 秒と試験体上部構造の固有周期に近いことか ら，同調したことが原因と考えられる。これ以外の 時間帯では，必ずしも桁変位の周期は 1 秒前後とな っておらず同調だけが原因であるとは言い切れない。 ただし，その大きさは振動台最大加速度に比較して 小さいことから構造安全上の問題は小さいものと考 えられる。

\section{c) 鉛直地震動の影響}

ここでは，最大の応答を示すケース $\mathrm{T} 1$ とこれに 基礎鉛直地震動の影響を加味するケース $\mathrm{T} 2$ の比較 を行うものとする. 図-12は，ケース $\mathrm{T} 1$ および $\mathrm{T} 2$ における桁相対変位，す心゙り支承摩擦力，面圧，お よび履歴曲線を比較したものである，時刻歴応答は， 両ケースの影響を明瞭にするために 10 秒までのデ ータを抽出している，図-8，図-9に示寸ように，振 動台の水平加速度はほぼ等しく, 鉛直加速度は，4 秒付近において, ケース $\mathrm{T} 2$ がケース $\mathrm{T} 1$ の 2 倍程度 の加速度を有している。

桁相対変位の最大值は, ケース $\mathrm{T} 1$ で $81.7 \mathrm{~mm}$, ケース $\mathrm{T} 2$ で $58.5 \mathrm{~mm}$ となっており，摩擦力の時刻 歴応答は同様の傾向を示している，次にす心゙り支承 の面圧を比較する. 図から明らかなように，ケース $\mathrm{T} 1$ と $\mathrm{T} 2$ で大きな面圧の差が認められ，鉛直地震動 の影響が大きいことがわかる。なお，4 個の支承の 面圧はほぼ同一であることを確認している。 


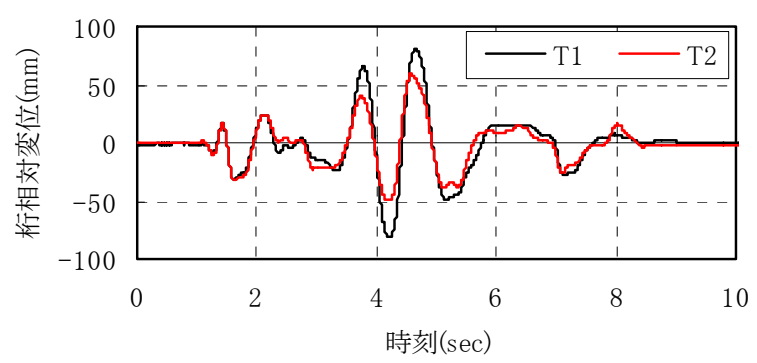

a) 桁相対変位

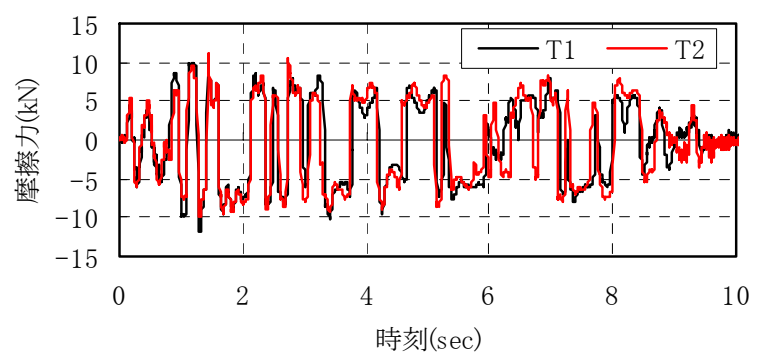

b) すべり支承摩擦力

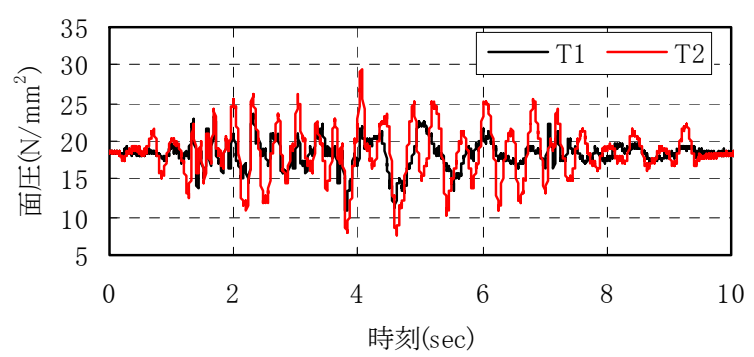

c)すべり支承面圧

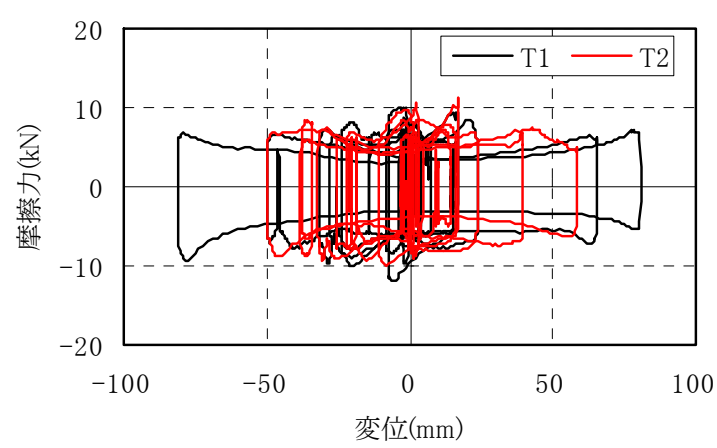

d) すべり支承の履歴曲線

図-12 ケース $\mathrm{T} 1$ および $\mathrm{T} 2$ における応答比較

さらに，前述の免震効果をケース $\mathrm{T} 2$ について図13に示す.この図からも $2 \mathrm{~m} / \mathrm{s}^{2}$ 以上の領域において は $\mathrm{T} 1$ と同様の免震効果が得られており, 鉛直加速 度の大きさの違いは見られない。ただし， $2 \mathrm{~m} / \mathrm{s}^{2}$ 以 下の領域においては増幅影響がやや $\mathrm{T} 1$ に比べると 低下している。これは，前述の免震効果で述べた同 調現象に起因する，ケース $\mathrm{T} 1$ と $\mathrm{T} 2$ の $2 \mathrm{~m} / \mathrm{s}^{2}$ 以下の 振動台水平加速度の入力誤差が主として影響したも のであると考えられる。

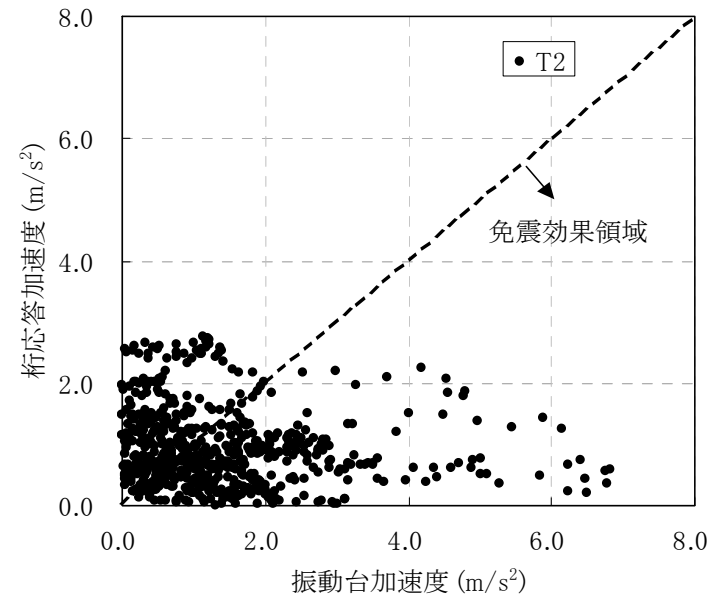

図-13 免震効果（ケース T2）

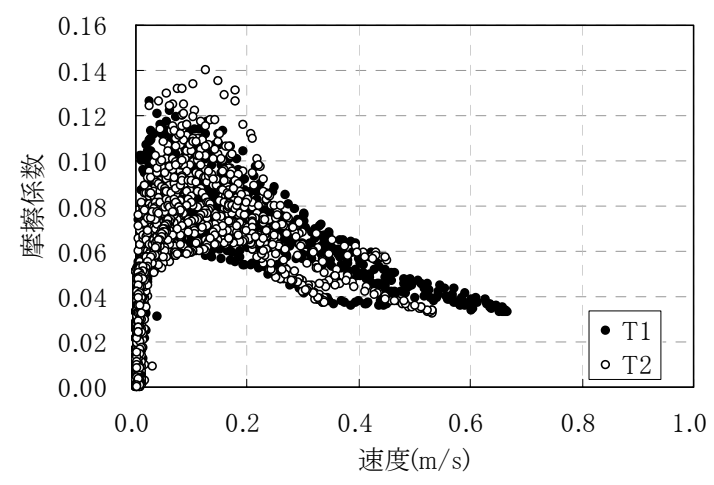

図-14 摩擦係数の速度依存性比較

なお，鉛直加速度の影響については，これらの実 験結果から定量的な評価を行うことは困難であるこ とから，後述の解析でこれらの結果を検証する。

d) 速度 · 面圧依存性

ケース T1 と T2 の 0.005 秒間隔での各すべり速度 と摩擦係数の関係を図-14に示す. この図より，0〜 $0.1 \mathrm{~m} / \mathrm{s}$ の範囲では $\mu=0 \sim 0.13$ 程度となり, $0.5 \mathrm{~m} / \mathrm{s}$ を 超えると $\mu=0.03 \sim 0.04$ に漸近することがわかる. こ の速度依存性は, 従来の PTFE すべり材とステンレ ス鋼板の組み合わせによるすべり支承の特性，つま り, すべり速度が増加すると摩擦係数が増加し 0.1 〜 0.15 に漸近する傾向と大きく異なっている. また， 図上データは 0.005 秒間隔のデータであることから， 摩擦係数のばらつきは大きく表現されているが，平 均的な摩擦係数による設計可能性は後述する.

ケース T1 と $\mathrm{T} 2$ を比較すると, 同様の速度依存 性が見られるが，す心゙り速度 $0.1 〜 0.2 \mathrm{~m} / \mathrm{s}$ において は T2 の方がやや大きな值を示している.これは, このすべり速度域において面圧が低かったものと想 定される。これを明らかにするために，面圧と摩擦 


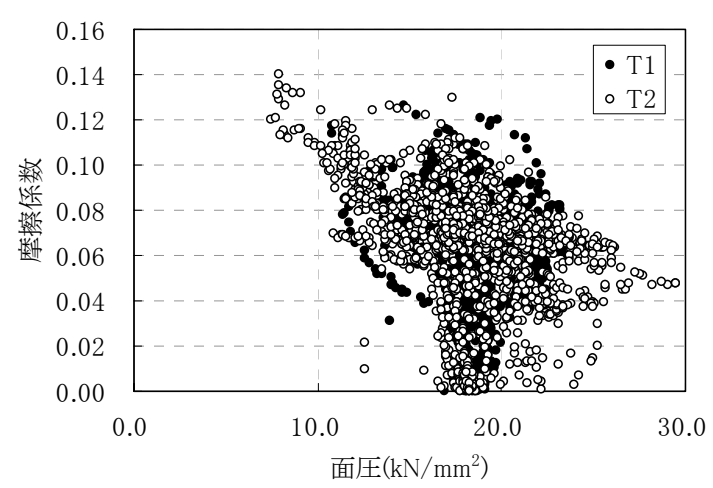

図-15 摩擦係数の面圧依存性

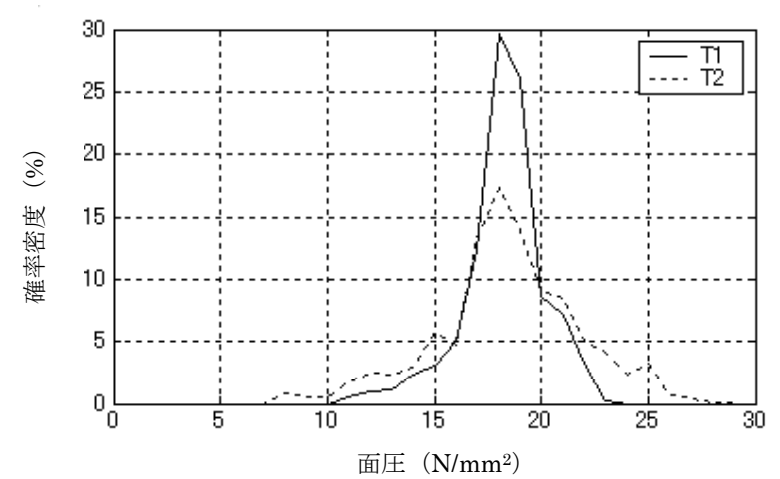

図-16 振動台実験結果から求めた面圧分布

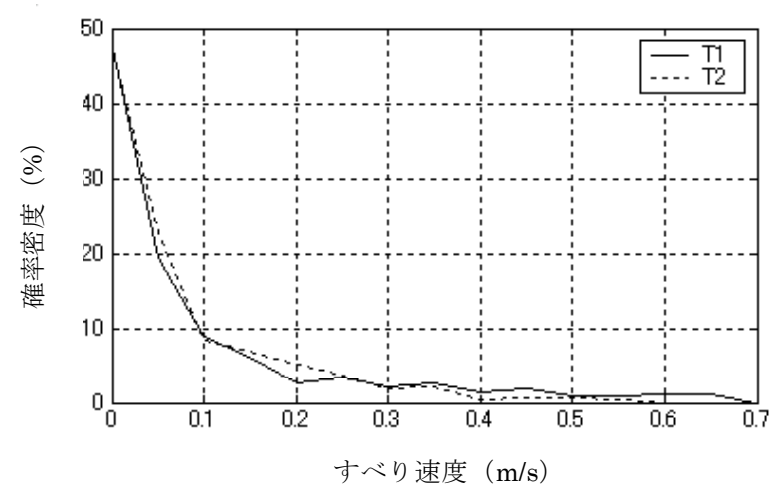

図-17 振動台実験結果から求めたすべり速度分布

係数の関係を調べた（図-15参照）。この図より明 らかなように摩擦係数が 0.1 以上であるデータにお いて, 面圧 $10 \mathrm{kN} / \mathrm{mm}^{2}$ 以下は, ケース $\mathrm{T} 2$ のものが 支配的となっており，上記の推定に一致するもので ある，さらに，面圧およびすべり速度の変動を確認 するために, 確率密度を求めた。 その結果は, 図16, 図-17に示すとおりである。面圧に関しては, ケース $\mathrm{T} 1$ と $\mathrm{T} 2$ ともに死荷重時面圧 $19.5 \mathrm{~N} / \mathrm{mm}^{2}$ の 值を中心とした分布を示しているが，鉛直加速度の 大きい $\mathrm{T} 2$ の変動幅の方が大きいことがこの図から も明らかである。すべり速度の変動に関しては,

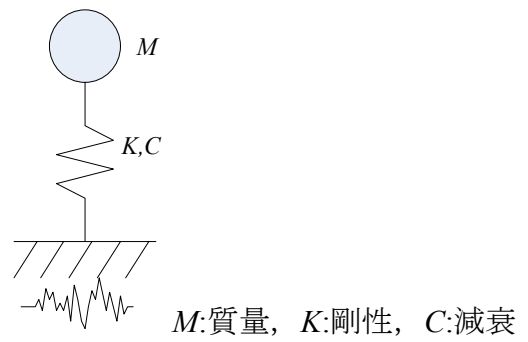

図-18１自由度系モデル

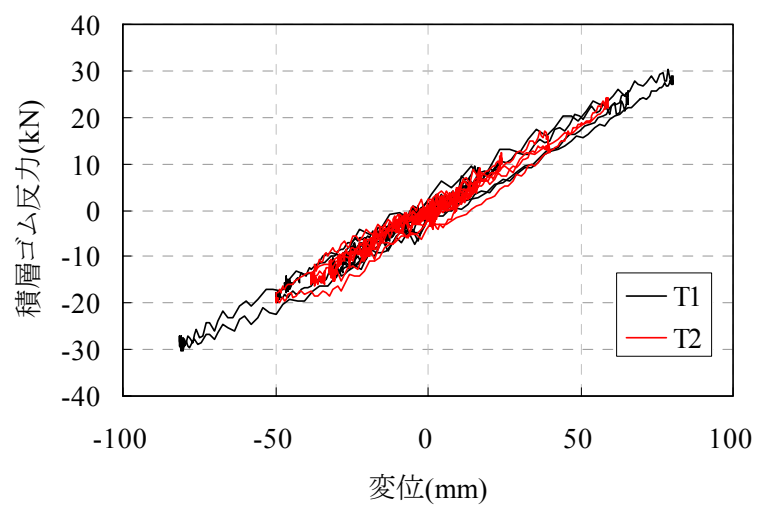

図-19 積層ゴムの特性

T1，T2 ともにほぼ同様であるが，T1 の方がやや大 きい最大速度を示している.

\section{3. 振動台実験の解析的検証と設計モデル構築}

\section{(1) 解析モデルと入力加速度}

振動台実験を図-18のような 1 自由度系にモデル 化し, 実験結果の再現解析を実施するとともに, 設 計モデル構築を行った.

具体的には，図のモデルに，実験における振動台 の加速度波形を入力し, 桁の応答および床組免震系 （すべり支承, 積層ゴム）の履歴特性を比較する. 各要素のモデル化は下記のとおりである.

\section{a) 積層ゴムモデル}

積層ゴムモデルを評価するに際して，振動台実験 結果より, 次式により積層ゴムに作用している反力 を逆算した.

$$
F_{r}=M_{g} \cdot A_{g}-F_{s}
$$

ここで, $M_{g}$ : 桁質量, $A_{g}$ : 杵加速度, $F_{s}$ : すべり支 承摩擦力， $F_{r}$ : 積層ゴム反力である.

上記の結果により求めた実験ケース $\mathrm{T} 1$ と T2 の 反力・変位関係を図-19に示す。ケース T3，T4 お 


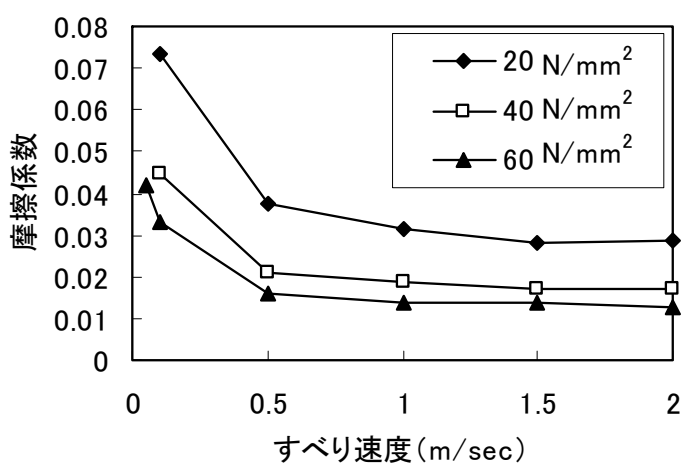

図-20 要素実験によるすべり速度一摩擦係数の関係

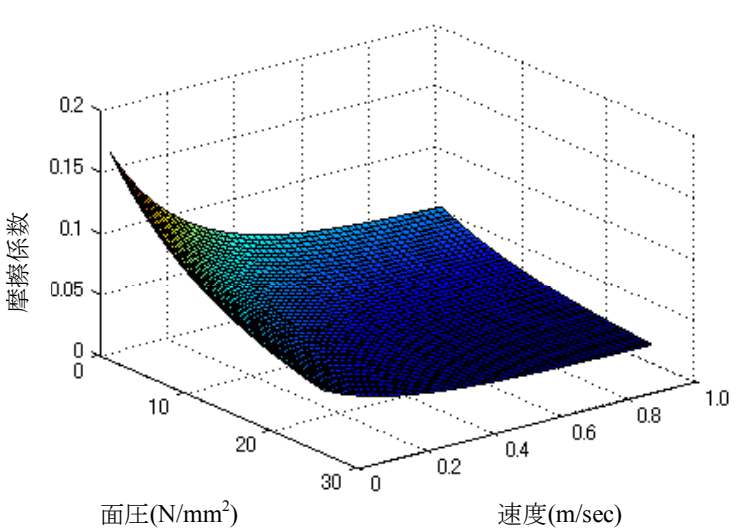

図-21 摩擦係数のすべり速度・面圧依存性

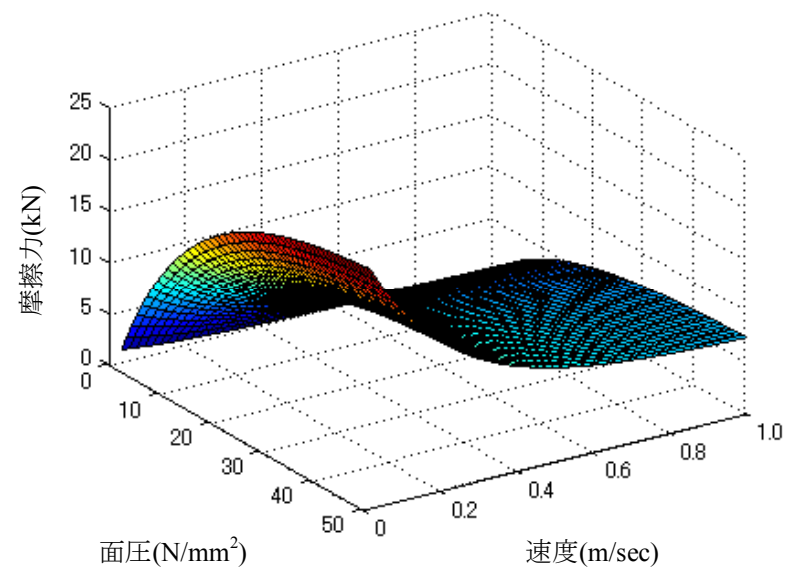

図-22 摩擦力のすべり速度・面圧依存性

よび T5 の等価剛性も各々, 同様の值を示したこと から，積層ゴム等価剛性として，5 ケース平均值の $K=0.17 \mathrm{kN} / \mathrm{mm}$ を以降採用することとした.

積層ゴムの減衰については, 粘性減衰にてモデル 化した. 減衰定数としては, 実験ケース $\mathrm{T} 1$ の等価 減衰定数 $4.7 \%$ を参考に $5 \%$ を設定した他，一般的な 值である $2 \%$ も比較の意味で設定した。

\section{b) すべり支承モデル}

別途実施されたすべり支承要素実験結果から，す ベり支承に発生する速度 - 摩擦係数の関係を求めた 結果を図-20に示す.

ここでは, 高橋らの研究 ${ }^{8)}$ を参考に, 要素実験結 果から求めた速度 - 面圧 - 摩擦係数の関係より, 最 小 2 乗法による近似曲線を設定し，速度 - 面圧依存 モデルを式(2)のとおり構築した。 なお，第 1 項目 は速度依存性に関する部分で，速度が増すにつれ摩 擦係数が減少する特性を表現し，第 2 項目は面圧に 関する部分で面圧が高いほど摩擦係数が減少する特 性を表している.

$$
\mu=\left[s_{\min }+s_{0} \cdot \exp (-n \cdot v)\right] \frac{[1-\exp (-k \cdot p)]}{p}
$$

ここで, $v$ : すべり速度 $(\mathrm{m} / \mathrm{s}), p$ : 面圧 $\left(\mathrm{N} / \mathrm{mm}^{2}\right)$, $s_{0}$ : 静摩擦係数に対応するせん断強さに関するパラ メータ, $s_{\min }$ : 動摩擦係数最小值に対応するせん断 強さのパラメータ, $n$ : 速度依存のパラメータ, $k$ : 面圧依存のパラメータである.

図-21は，式(2)を用いて，面圧とすべり速度を変 化させた低摩擦型すべり支承の摩擦係数特性を表し ている。この図から，面圧が上昇すれば摩擦係数は 低下し，すべり速度が上昇すれば摩擦係数が低下寸 る特性が連続的に表現されていることがわかる。

また, 面圧は上記の摩擦係数の変動要因であると ともに, 鉿直力の変動要因であることを踏まえ, 直 接, 摩擦力特性を把握するために, 面圧-速度-摩擦 力関係を図-22に示す．なお，摩擦力算定に必要な 諸元は試験体に合わせている。この図から， $20 \mathrm{~N} / \mathrm{mm}^{2}$ 程度までは面圧が増加するにつれ摩擦力が 増加するが，それ以降においては摩擦係数の低下の 影響が大きくなり，いずれのすべり速度においても 摩擦力は頭打ち傾向を示すことがわかる.

\section{(2) 再現解析}

式(2)により設定した速度 - 面圧依存性のモデル の妥当性を検証するために，代表的な実験ケースの 再現解析を行った。すべり速度，面圧については実 験結果を用いている，検討ケースは，表-8の A1〜 A8 である. A1〜 A3 は T1, A4, A5 は T2, A7 は T3，A8 は T4 の再現解析である。なお，A6は T2の 鋁直加速度を 2 倍にした仮想ケースである。主要な 応答值は表-9〜表-11に示寸とおりである. 
表-8 解析ケース一覧

\begin{tabular}{|c|c|c|c|c|c|}
\hline \multirow{2}{*}{$\begin{array}{l}\text { 目 } \\
\text { 的 }\end{array}$} & \multirow{2}{*}{$\begin{array}{c}\text { 解析 } \\
\text { ケー } \\
\text { ス }\end{array}$} & \multirow{2}{*}{$\begin{array}{c}\text { 再現 } \\
\text { ケー } \\
\text { ス }\end{array}$} & \multirow{2}{*}{$\begin{array}{c}\text { すべり支承 } \\
\text { モデル }\end{array}$} & \multicolumn{2}{|c|}{ 積層ゴムモデル } \\
\hline & & & & $\begin{array}{c}\text { 剛性 } \\
(\mathrm{kN} / \mathrm{mm})\end{array}$ & $\begin{array}{l}\text { 減衰 } \\
\text { 定数 }\end{array}$ \\
\hline \multirow{8}{*}{$\begin{array}{l}\text { 再 } \\
\text { 現 } \\
\text { 解 } \\
\text { 析 }\end{array}$} & A1 & \multirow{3}{*}{$\mathrm{T} 1$} & $\begin{array}{l}\text { 速度一面圧 } \\
\text { 依存モデル }\end{array}$ & 0.170 & $2.0 \%$ \\
\hline & $\mathrm{A} 2$ & & $\begin{array}{l}\text { 速度一面圧 } \\
\text { 依存モデル }\end{array}$ & 0.170 & $5.0 \%$ \\
\hline & A3 & & $\begin{array}{c}\text { 速度依存モ } \\
\text { デル }\end{array}$ & 0.170 & $5.0 \%$ \\
\hline & A4 & \multirow{2}{*}{$\mathrm{T} 2$} & $\begin{array}{l}\text { 速度－面圧 } \\
\text { 依存モデル }\end{array}$ & 0.170 & $5.0 \%$ \\
\hline & A5 & & $\begin{array}{c}\text { 速度依存モ } \\
\text { デル }\end{array}$ & 0.170 & $5.0 \%$ \\
\hline & A6 & $\mathrm{T} 2{ }^{\prime}$ & $\begin{array}{l}\text { 速度一面圧 } \\
\text { 依存モデル }\end{array}$ & 0.170 & $5.0 \%$ \\
\hline & A7 & $\mathrm{T} 3$ & $\begin{array}{l}\text { 速度一面圧 } \\
\text { 依存モデル }\end{array}$ & 0.170 & $5.0 \%$ \\
\hline & A8 & $\mathrm{T} 4$ & $\begin{array}{l}\text { 速度－面圧 } \\
\text { 依存モデル }\end{array}$ & 0.170 & $5.0 \%$ \\
\hline
\end{tabular}

注）A6 は T2 の鉛直加速度を 2 倍にしたケース

表-9 桁相対変位, すべり支承摩擦力の最大応答值比較

\begin{tabular}{|c|c|c|c|c|}
\hline \multirow{2}{*}{$\begin{array}{c}\text { 解析厅 } \\
\text { ース }\end{array}$} & \multicolumn{2}{|c|}{ 解析 } & \multicolumn{2}{|c|}{ 実験 } \\
\hline & $\begin{array}{c}\text { 桁相対変 } \\
\text { 位 }(\mathrm{mm}) \\
\end{array}$ & $\begin{array}{c}\text { 摩擦力 } \\
(\mathrm{kN})\end{array}$ & $\begin{array}{c}\text { 桁相対変 } \\
\text { 位 }(\mathrm{mm}) \\
\end{array}$ & $\begin{array}{c}\text { 摩擦力 } \\
(\mathrm{kN}) \\
\end{array}$ \\
\hline A1 & 89.8 & 8.7 & \multirow{3}{*}{81.7} & \multirow{3}{*}{12.0} \\
\hline $\mathrm{A} 2$ & 82.0 & 8.7 & & \\
\hline A3 & 79.2 & 8.1 & & \\
\hline A4 & 60.6 & 9.1 & \multirow{3}{*}{58.5} & \multirow{3}{*}{11.3} \\
\hline A5 & 59.6 & 7.8 & & \\
\hline A6 & 66.7 & 9.8 & & \\
\hline A7 & 17.8 & 8.2 & 15.7 & 11.1 \\
\hline A8 & 11.6 & 8.4 & 10.3 & 12.0 \\
\hline
\end{tabular}

積層ゴムの減衰に着目すると, ケース A1 $(h=2 \%)$ と A2 $(h=5 \%)$ の比較において，後者の 方が, 解析值と実験值はいずれの応答も良好な一致 をみている。これは，解析対象としている実験ケー ス $\mathrm{T} 1$ の積層ゴム等価減衰定数が約 5\%であったこ とと整合している。この結果をもとに A3 以降のケ 一スの積層ゴム減衰定数を $5 \%$ と設定している.

次に, 代表的なケースとして, 図-23にケース A2 の桁相対変位, 摩擦力の時刻歴応答, およびす べり支承の履歴曲線を各実験值と比較する. 全体的 に，いずれも実験值をよく再現していることがわか るが, 摩擦力の時刻歴の振動初期（1〜2 秒前後） において実験值の方が大きくなる傾向がみられる.

表-9における摩擦力の相違は，このように初ループ の摩擦係数が高くなるすべり回数依存性によるもの と判断される。また, すべり支承の履歴曲線から変
表-10 支承部履歴面積比較

\begin{tabular}{|c|c|c|c|c|}
\hline \multirow{2}{*}{$\begin{array}{l}\text { 解析厅 } \\
\text { 一ス }\end{array}$} & \multicolumn{2}{|c|}{ 解析 $(\mathrm{kN} \cdot \mathrm{mm})$} & \multicolumn{2}{|c|}{ 実験 $(\mathrm{kN} \cdot \mathrm{mm})$} \\
\hline & 全体系 & すべり支承 & 全体系 & すべり支承 \\
\hline A1 & 1610 & 1014 & \multirow{3}{*}{2,089} & \multirow{3}{*}{1,370} \\
\hline $\mathrm{A} 2$ & 1767 & 942 & & \\
\hline $\mathrm{A} 3$ & 1773 & 1005 & & \\
\hline A4 & 1395 & 890 & \multirow{3}{*}{1,549} & \multirow{3}{*}{1,174} \\
\hline A5 & 1317 & 834 & & \\
\hline A6 & 1537 & 944 & & \\
\hline A7 & 443 & 407 & 330 & 324 \\
\hline A8 & 269 & 234 & 353 & 343 \\
\hline
\end{tabular}

表-11 支承部等価減衰定数比較

\begin{tabular}{|c|c|c|c|c|}
\hline \multirow{2}{*}{$\begin{array}{l}\text { 解析ケ } \\
\text { 一ス }\end{array}$} & \multicolumn{2}{|c|}{ 解析 } & \multicolumn{2}{|c|}{ 実験 } \\
\hline & 全体系 & すべり支承 & 全体系 & すべり支承 \\
\hline A1 & $9 \%$ & $21 \%$ & \multirow{3}{*}{$11 \%$} & \multirow{3}{*}{$25 \%$} \\
\hline $\mathrm{A} 2$ & $10 \%$ & $22 \%$ & & \\
\hline A3 & $11 \%$ & $26 \%$ & & \\
\hline A4 & $14 \%$ & $26 \%$ & \multirow{3}{*}{$17 \%$} & \multirow{3}{*}{$32 \%$} \\
\hline A5 & $13 \%$ & $29 \%$ & & \\
\hline A6 & $14 \%$ & $23 \%$ & & \\
\hline A7 & $36 \%$ & $52 \%$ & $32 \%$ & $42 \%$ \\
\hline A8 & $32 \%$ & $40 \%$ & $44 \%$ & $48 \%$ \\
\hline
\end{tabular}

位 0 付近で摩擦力が最小となる鼓形の特性が見られ， 低摩擦型す心゙り支承の特性が良く表現されているこ とがわかる。なお，実験ケース T3，T4 に相当する 地震動に対しても同様のモデルを用いてその再現性 を検討した結果, 非常に小さな応答ながら解析值と 実験值はほぼ同じ值を示していることを確認した。

表-9に示される桁相対変位に着目して面圧依存性 について考察する. 面圧変動の小さな実験ケース T1 の再現解析における, 面圧依存性考慮モデル （解析ケース A2）と面圧依存性無視モデル（解析 ケース A3）の差異は $82 \mathrm{~mm}$ と $79.2 \mathrm{~mm}$ と小さく, 面圧依存性考慮の影響は小さいと判断される.

次に面圧変動の大きな実験ケース T2 の再現解析 ケースである A4，A5 および面圧変動を 2 倍とした A6 を比較すると, 各值は, $60.6 \mathrm{~mm}, 59.6 \mathrm{~mm}$, $66.7 \mathrm{~mm}$ となっている.つまり, 実験レベルの鉛直 加速度であれば面圧変動の影響は小さいが，その 2 倍程度の鉛直加速度を与えると面圧変動の増加に伴 い桁相対変位が若干増加寸る傾向が見られる.

ところで，面圧変動による最大応答変位は，面圧 変動の大きさとともに水平振動と鉛直振動の位相に も関係すると考えられる，そこで，面圧変動および 位相差をパラメータとして, 桁の最大応答変位の変 化を検討した。 


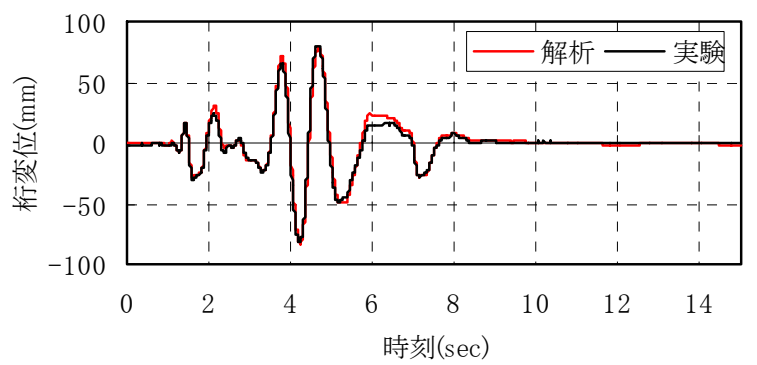

a) 桁相対変位

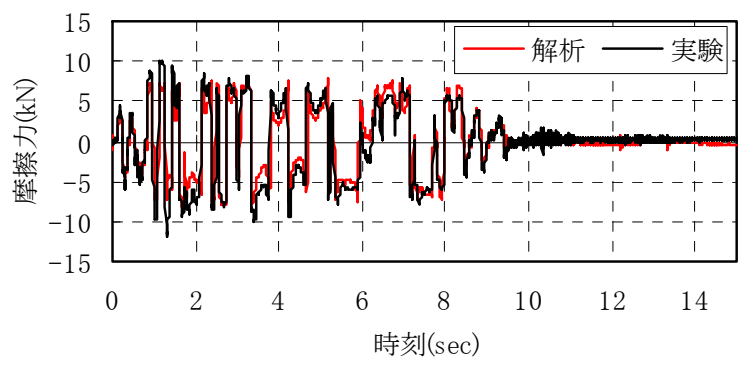

b) 摩擦力

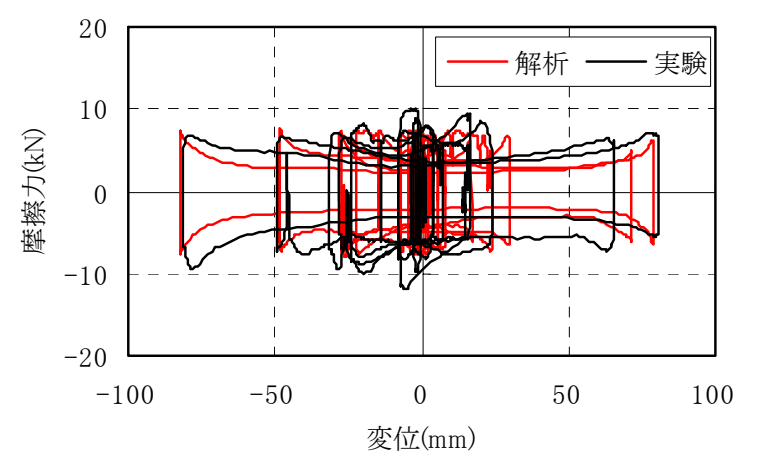

c) 履歴曲線

図-23 ケース A2（速度-面圧依存モデル）による再現性

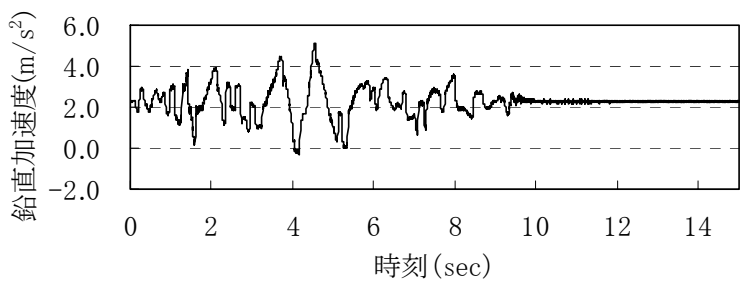

a) 桁の水平加速度適用波形

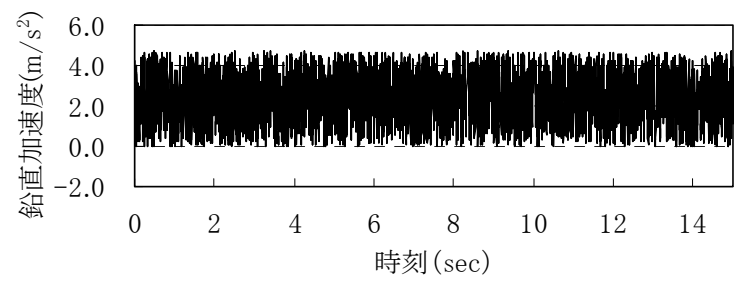

b) ホワイトノイズ適用波形

図-24模擬地震波による鉛直加速度

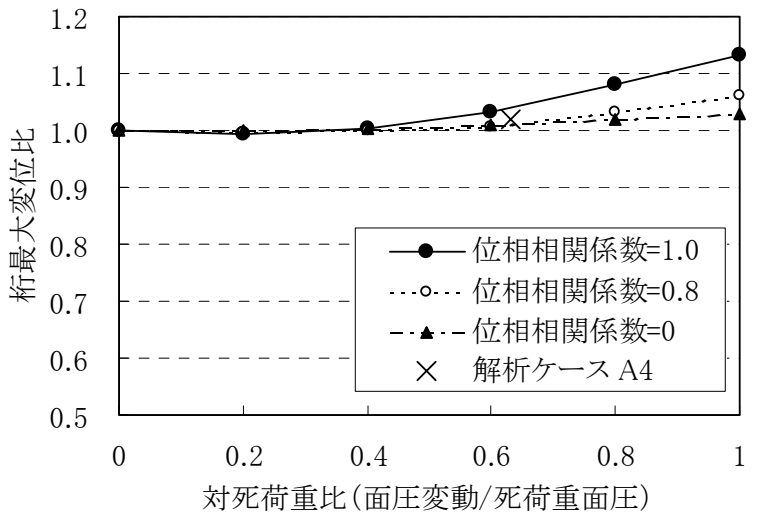

図-25 無次元化した面圧変動と桁最大変位の関係

ここで，面圧変動の大きさは鉛直振動による面圧 振幅と死荷重時面圧の比率により無次元化した. 水 平, 鉛直加速度の位相差については, 鉛直入力加速 度と桁の水平応答加速度波形との相互相関係数をパ ラメータとして検討を行った。相互相関係数が 1.0 の波形としては，桁の水平応答加速度波形を，相互 相関係数 0 の波形としては，ホワイトノイズを設定 した（図-24）.また，相互相関係数 $=0.8$ の波形は， 両者を時間領域で加算した上で最大加速度を適合さ せることにより作成した。

これらの振幅調整された波形による解析結果を 図-25に示す。この図から，対死荷重比が 0.5 程度 であれば，いずれのケースも桁の最大変位比（面圧 変動が無い場合の林最大変位に対する比率）はほぼ 1.0 であり影響は少ないが，対死荷重比が 1.0 程度 となると桁最大変位比は最大 1.1 を上回り, やや影 響が見られることがわかる。

位相特性に着目すると, 相互相関係数 1.0 の場合 には，桁最大応答比に与える影響が比較的大きく， 鉛直振動と水平振動が無相関の場合には影響が小さ い結果となっている. なお，実験ケース T2 を再現 した解析ケース A4 の場合，椼の水平応答加速度と 鉛直加速度の相関係数は 0.24 程度, 対死荷重比は 0.63 であり，上記の解析結果と整合していることが 確認できる.

\section{(3) 設計モデル構築}

実務設計，特に複雑な長大橋の設計においては, すべり支承の履歴モデルを簡便なものとすることが 望ましい。 そこで, 速度依存性が動的挙動へ与える 影響を確認するために, 実験結果と速度依存性を考 慮しない剛塑性モデルによる解析結果との比較を実 施した。 なお，面圧依存性については，前述の解析 結果に基づき考慮しない。 


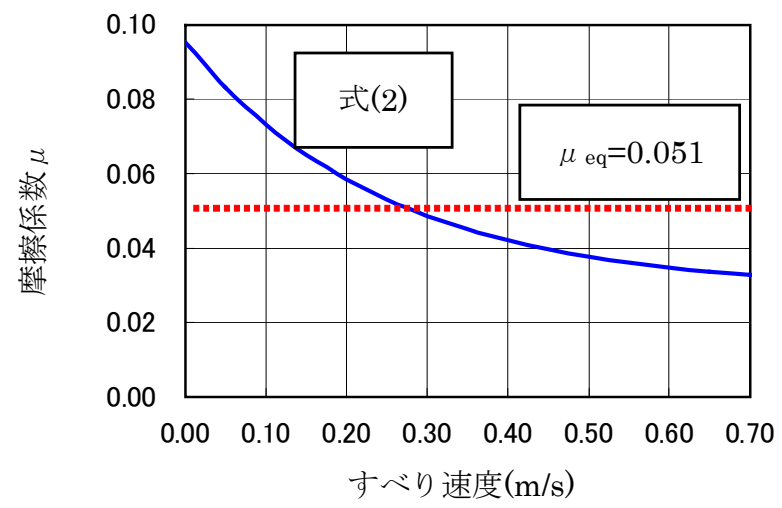

図-26 等価摩擦係数 $\left(\mu_{e q}\right)$

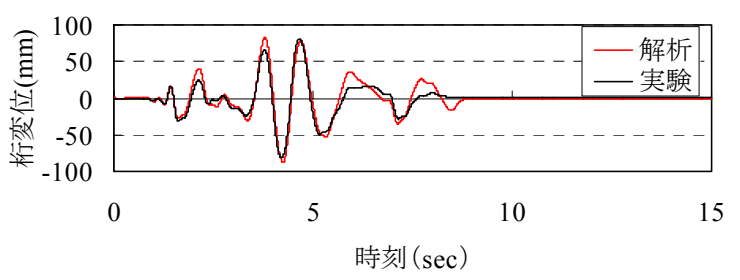

a) 桁相対変位

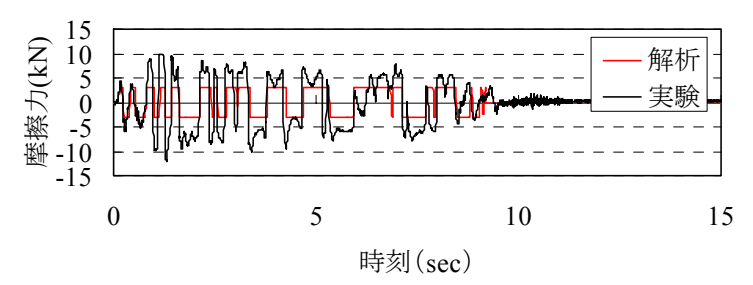

b) 摩擦力

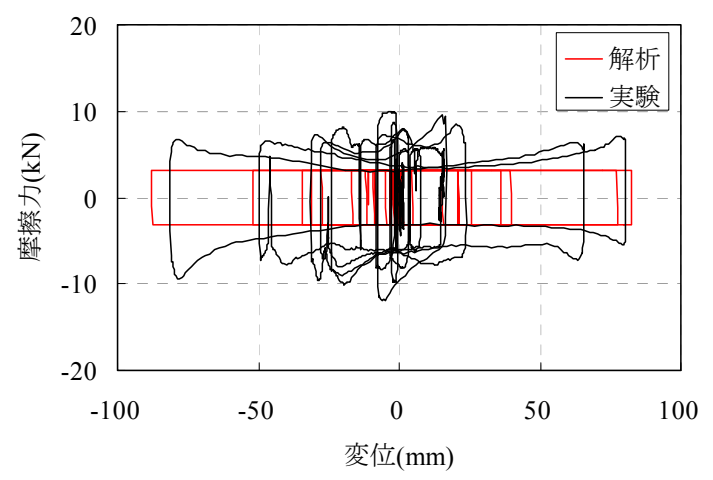

c) 履歴曲線

図-27 剛塑性モデル $(\mu=0.033)$

解析モデルとしては，2 ケースを設定した。一つ は, 最大すべり速度時の摩擦係数に着目したモデル で，式(2)に振動台実験時の最大すべり速度 $\nu=0.70 \mathrm{~m} / \mathrm{s}$ を考慮した摩擦係数 $\mu=0.033$ に対応する 摩擦力を塑性值とする剛塑性モデルである。もう一 つは, 式(2)より得られる速度-摩擦係数曲線の等価 面積により得られる等価摩擦係数に着目して, $\mu_{e q}$

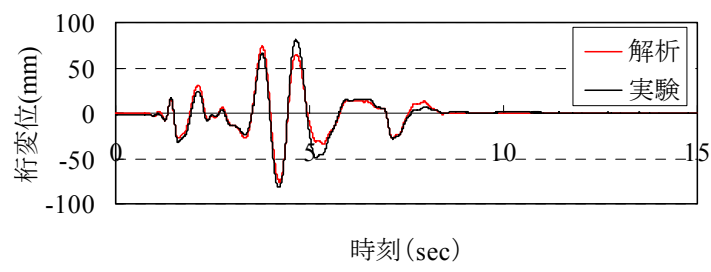

a) 桁相対変位

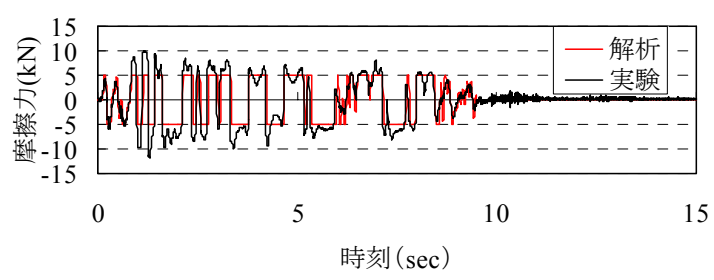

b) 摩擦力

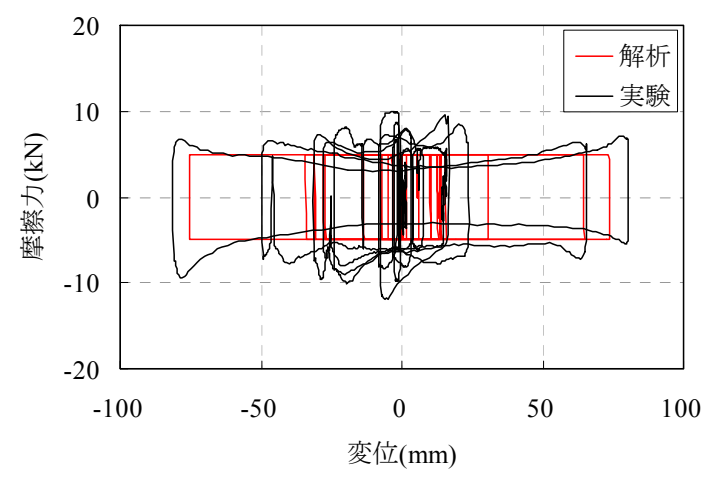

c) 履歴曲線

図-28 剛塑性モデル $\left(\mu_{e q}=0.051\right)$

$=0.051$ に対応する摩擦力を塑性值とする剛塑性モデ ルである（図-26参照）。

剛塑性モデル $\mu=0.033$ の結果を図-27, $\mu_{e q}=0.051$ の結果を図-28 に示す. 桁相対変位, 支承摩擦力, および履歴曲線ともに, 後者の等価摩擦係数モデル の適合性が高いことがわかる. これは，結果的に後 者のモデルがすべり支承の最大履歴曲線に着目して, この履歴を等価な矩形モデルに置き換えたことにな るためである。

つまり，最大履歴曲線におけるすべり速度は，ゼ ロから最大すべり速度の間で分布しており，これを 平均化したモデル設定の考え方が妥当であることを 示すものである.

以上の結果から，速度依存性曲線において設計で 想定される最大すべり速度における等価面積を与え る等価摩擦係数に対応する摩擦力を塑性值とした剛 塑性モデルを便宜上，設計に用いて良いことが示さ れた。 なお，最大すべり速度を求める際に支承モデ ルが必要になり，実設計においては繰り返しによる 収束計算が必要になる場合がある。 


\section{4. 結論}

長大卜ラス橋に採用されている床組免震構造にお いて新たに開発された低摩擦型すべり免震支承と積 層ゴムからなるシステムの振動台実験および解析的 検証を実施した。ここでは, 特に, 本構造の特徵で あるトラス主構により増幅された鉛直振動による影 響に着目した。本検討により得られた結論は以下の とおりである。

1.これまで明らかとされていなかった積層ゴム を併設したシステムにおける低摩擦型すべり 支承の速度および面圧依存性を明らかとする とともに，すべり速度の速いケースにおける 履歴曲線が鼓形を呈することを確認した。

2. 低摩擦型すべり支承に関して, 面圧および速 度依存性を考慮した数式モデルを構築し，振 動台実験結果と比較した結果, 桁相対変位, 摩擦力, 履歴曲線において比較的良い適合性 が見られ，解析モデルの妥当性が示された。

3. 妥当性の認められたモデルを用いて, 鉛直振 動の影響を検討したが，設計地震動レベルで は影響はほとんどないことが確認された。し かし，鉛直面圧変動と死荷重時面圧の比率が 0.5 を上回ると桁相対変位増大の傾向が見られ ることがわかった。

4. 静止時から設計最大す心゙り速度における，す べり速度-摩擦係数曲線の面積と等価な面積を 与える摩擦係数を等価摩擦係数とすることを 提案し,この摩擦力を塑性值とした剛塑性モ デルを設計に用いて良いことを示した。

謝辞：本実験については，阪神高速道路株式会社技 術審議会耐震設計分科会（主査：高田至郎神戸大学 教授）の委員にご審議していただき貴重なご意見を 頂いた。低摩擦型すべり支承の開発および試験デー 夕提供に際してはオイレス工業（株）の関係者に, また，実験試験体設計に際しては，港大橋而震補強 工事 JV 東谷修氏，大濱浩二氏にご協力頂いた。ま た，解析においては中央復建コンサルタンツ（株） 中谷武弘氏に貴重なご意見を頂いた。ここに皆様に 深く感謝いたします。

\section{参考文献}

1）金治英貞，鈴木直人，香川敬生，渡邊英一：長大卜 ラス橋の対震性能向上化における設計入力地震動と 損傷制御構造，土木学会論文集，No.787/I-71, pp.1-19, 2005.4 .
2）吉川実，金治英貞，宇野裕恵 : 兵庫県南部地震によ り被災した既設 PC 高架橋の免震復旧構造, 土木学 会 第 1 回免震・制震コロキウム講演論文集, 1996.11.

3）伊津野和行, 袴田文雄, 中村一平 : 機能分離型支承 装置の動特性と設計手法に関する研究，土木学会論 文集，No.654/I-52,pp.233-244，2000.7.

4）阪神高速道路公団：すべり免震支承システム設計手 引き，2003.5.

5) 岡本晋, 藤井俊二, 尾崎大輔, Constantinou, M.C., Tsopelas, P.C. : すべり方式免震システムを有する橋 梁の動特性に関する実験的研究，土木学会論文集， No.507/I-30, pp.167-177, 1995.1.

6）岡本晋, 深沢泰晴, 藤井俊二, 尾崎大輔 : すべり方 式免震システムを有する橋梁の地震時挙動特性，土 木学会論文集，No.513/I-31，pp.191-200，1995.4.

7）川島一彦：動的解析における摩擦力のモデル化に関 する一考察, 土木学会論文集, No.309, pp.151-154, 1981.

8）高橋良和，日比雅一，家村浩和：各種依存性を考慮 した滑り型免震支承の数值モデルに関する一考察, 土木学会応用力学論文集, Vol.8, pp.701-708, 2005.8.

9）姫野岳彦，運上茂樹：支承部における摩擦特性のモ デル化とその評価式に関する検討, 土木学会地震工 学論文集, Vol.27, 2003.12.

10）中谷武弘, 廣瀬彰則, 高橋良和, 家村浩和：すべり 摩擦支承の振動台実験に関する解析的検証，第 8 回 地震時保有耐力法に基づく橋梁等構造の耐震設計に 関するシンポジウム講演論文集，2005.2.

11) AASHTO Guide Specifications for Seismic Isolation Design, 2nd Edition, American Association of State Highway and Transportation Officials, Washington, D.C., 1999.

12）金治英貞：米国カリフォルニア州の長大橋の耐震補 強と日米設計法の比較, 第 5 回 橋梁構造等の耐震設 計法に関する講習会テキスト, 土木学会 地震工学委 員会 地震時保有耐力法に基づく耐震設計法の開発に 関する研究小委員会, 2002.10 .

13）高田佳彦，浜田信彦，金治英貞：長大ゲルバートラ 又橋の床組免震化における低摩擦係数型すべり支承 の特性検討，第 25 回日本道路会議論文集，2003.11.

14）宮崎充，金治英貞，高田佳彦，東谷修，荒水照夫： 長大卜ラス橋の床組免震構造におけるす心゙り免震支 承の設計と性能, 第 8 回地震時保有耐力法に基づく 橋梁等構造の耐震設計に関するシンポジウム講演論 文集，2005.2.

15）大塚久哲，田中弘紀，横川英彰，金山亭，清水晋作， 
夏青 : 低摩擦すべり支承を有する連続桁橋の耐震性 に関する一考察，土木学会構造工学論文集，Vol.51A， 2005.3.

16）藤田亮一，森敦，金治英貞，伊津野和行：す心゙り免 震支承システムのパラメータが橋梁応答に及ぼす影 響, 土木学会地震工学論文集, Vol.27, 2003.12.
17 ) Krawinkler, H. and Moncarz, P.D. : "Similitude requirements for dynamic models", Dynamic Modeling of Concrete Structures SP 73-1, Am. Concr. Inst., pp.1-22, 1982.

\section{SHAKING TABLE TEST AND ANALYTICAL STUDY ON LOW FRICTION SLIDING BEARINGS FOR FLOOR DECK ISOLATION SYSTEM}

\section{Hidesada KANAJI, Naoto SUZUKI, Hirokazu IEMURA, Yoshikazu TAKAHASHI, Tomohiro MINO and Yoshihiko TAKADA}

Properties for low-friction bearings, which have been developed for the floor isolation system of a long-span truss bridge, have not revealed. Therefore shaking table tests and analytical studies considering amplified vertical acceleration by main structure as well as horizontal acceleration have been carried out. The results show that the friction coefficient under the high speed is smaller than that under the low speed, and the effect of vertical input can be neglected under the design grond motion. In addition, a simplified design model is here proposed. It is rigid-plastic model appling the equivalent coefficient concept considering the velocity-friction coefficient curve below the design maximum velocity. 